\title{
Prevalence and associated factors of Treponema pallidum infection in a rural area of southwestern China
}

Ying Shi ${ }^{1,2,3 \dagger}$, Ya Yang ${ }^{1,2,3 \dagger}$, Yingjian Wang ${ }^{1,2,3}$, Dongjian Yang ${ }^{1,2,3}$, Yu Yang ${ }^{1,2,3}$, Shurong Dong ${ }^{1,2,3}$, Chunlin Li $i^{1,2,3}$, Yue Chen ${ }^{4}$, Qingwu Jiang ${ }^{1,2,3}$ and Yibiao Zhou ${ }^{1,2,3^{*}}$

\begin{abstract}
Background: Epidemiological data on Treponema pallidum infection are scarce from the southwestern region of China. The purpose of this study was to determine the distribution and determinants of T. pallidum infection in the region.

Methods: A community-based cross-sectional study of 2608 participants aged $\geq 14$ years was conducted in a rural area of southwestern China in 2014-15. A pretested questionnaire was used to collect sociodemographic characteristics and other factors associated with T. pallidum infection. The diagnoses of T. pallidum, human immunodeficiency virus (HIV), hepatitis B virus (HBV) and hepatitis $C$ virus ( $\mathrm{HCV}$ ) infections were determined by commercial test kits. Logistic regression analysis was used to determine the correlates for T. pallidum infection, and adjusted odds ratios (aORs) and 95\% confidence intervals (Cls) were calculated.

Results: The prevalence of T. pallidum infection was 1.2\% (95\% Cl 0.8 to 1.7\%). Risk factors varied by gender. In the male group, T. pallidum infection was significantly associated with ever injection drug use $(a \mathrm{OR}=9.42,95 \% \mathrm{Cl} 2.47$ to 35.87 ) and $\mathrm{HCV}$ infection ( $\mathrm{aOR}=13.28,95 \% \mathrm{Cl} 3.20$ to 51.70). In the female group, correlates for T. pallidum infection included spouse having syphilis ( $\mathrm{aOR}=126.66,95 \% \mathrm{Cl} 7.58$ to 2122.94), ever having blood transfusion $(\mathrm{aOR}=10.51,95 \% \mathrm{Cl} 1.58$ to 41.21$)$ and HBV infection ( $\mathrm{aOR}=4.19,95 \% \mathrm{Cl} 1.35$ to 10.93$)$.

Conclusions: The prevalence of T. pallidum infection was high in the rural area of southwestern China. Correlates for T. pallidum infection varied with sex specific. Intervention should be developed for the prevention and control of T. pallidum infection.
\end{abstract}

Keywords: Treponema pallidum, Syphilis, Risk factors, China

\footnotetext{
* Correspondence: ybzhou@fudan.edu.cn

†Ying Shi and Ya Yang contributed equally to this work.

${ }^{1}$ Fudan University School of Public Health, Building 8, 130 Dong'an Road,

Xuhui District, Shanghai 200032, China

${ }^{2}$ Key Laboratory of Public Health Safety, Fudan University, Ministry of

Education, Building 8, 130 Dong'an Road, Xuhui District, Shanghai 200032,

China

Full list of author information is available at the end of the article
}

C The Author(s). 2020 Open Access This article is licensed under a Creative Commons Attribution 4.0 International License, which permits use, sharing, adaptation, distribution and reproduction in any medium or format, as long as you give appropriate credit to the original author(s) and the source, provide a link to the Creative Commons licence, and indicate if changes were made. The images or other third party material in this article are included in the article's Creative Commons licence, unless indicated otherwise in a credit line to the material. If material is not included in the article's Creative Commons licence and your intended use is not permitted by statutory regulation or exceeds the permitted use, you will need to obtain permission directly from the copyright holder. To view a copy of this licence, visit http://creativecommons.org/licenses/by/4.0/. The Creative Commons Public Domain Dedication waiver (http://creativecommons.org/publicdomain/zero/1.0/) applies to the data made available in this article, unless otherwise stated in a credit line to the data. 


\section{Background}

Syphilis is a sexually and vertically transmitted disease (STD), which is caused by the spirochaete Treponema pallidum subspecies pallidum [1]. The World Health Organization (WHO) estimated that 17.7 million individuals aged 15-49 years had syphilis globally in 2012, with 5.6 million new cases every year [2]. In the low and middle-income countries, the risk for heterosexual spread of syphilis has declined in the general population but remains a challenge in some high-risk subpopulations, such as female sex workers (FSWs) and their male clients [1]. The infection of T. pallidum can cause cutaneous lesions, late complications such as neurologic and cardiovascular disease [3, 4], and congenital syphilis with other immediate complications, such as premature labor and low birthweight [5].

Syphilis was first recognized in mainland China in 1505 [6]. In 1949, the country experienced one of the biggest syphilis epidemics in human history [6]. The prevalence was $84 \%$ in prostitutes compared to $5 \%$ in general population in metropolitan area, and $2-3 \%$ in less developed cities in the 1950s [6]. Chinese government lunched an unprecedented campaign to make syphilis eradicated in 1960s [7]. However, syphilis has revived in China since the reform and opening up, and the prevalence raised about 5\% among FSWs and 3\% among their male clients [1]. Most of previous studies were executed among high-risk groups such as FSWs, IDUs, men who have sex with men, while few studies were carried out in general population.

Epidemiological data on syphilis prevalence is critical for developing public health strategies towards syphilis prevention, care and treatment. Our study site is one of the largest illicit drug distribution centers of China, and the largest autonomous prefecture of Yi nationality. Frequent casual sexual behavior is more tolerable among Yi people, which is related to an increased risk of $T$. pallidum infection [8]. In this region there are few female commercial sex workers and men who have sex with men among the $\mathrm{Yi}$ people [9]. In the current report, we aimed to determine the prevalence and factors associated with $T$. pallidum infection among local residents, mainly Yi people, in this region.

\section{Methods}

\section{Study site and population}

A population-based cross-sectional study was conducted from October 2014 to August 2015, in a Yi Prefecture of southwestern China, where almost half the residents are of the Yi ethnicity. It remains one of the most undeveloped regions in China as a result of mountainous terrains coupled with sparsely distributed population. A two-stage sampling was conducted in the study. Three counties $(\mathrm{Pg}, \mathrm{Zj}$, and $\mathrm{Mg}$ ) were selected in first step, whose residents shared similar health and sociodemographic characteristics, such as the proportion of minority, ethnic identity, age structure, and education level. Subsequently, four towns were selected from these counties by simple random sampling, where A and B from $\mathrm{Pg}$ County, $\mathrm{C}$ from $\mathrm{Zj}$ county and $\mathrm{D}$ from $\mathrm{Mg}$ county. Residents were eligible for investigation if they had to be over 14 years old and lived here for more than 6 months. The individual over14 years is permitted to have sexual practices, one of the criteria attributed to local Yi culture. We invited those who met the enrollment criteria to participate in our study. Village chiefs were asked to coordinate the side-by-side observations and the communication between local dialects and official language.

\section{Data collection}

Well trained local health professionals were responsible for questionnaire interview and screening test. All participants were informed of the objectives, contents, potential risk and benefits of this survey prior to the data collection. Study participants were assigned a unique identifier number to collect data confidentially. Face-to-face interviews were conducted and a structured questionnaire (see Additional file 1) covered sociodemographic characteristics (including age, sex, ethnicity, marital status, education, occupation, and household annual income), risky sexual behaviors (frequency of condom use and having multiple sexual partners), drug abuse and history of blood transfusion.

\section{Blood sample collection and diagnosis}

All participants were screened for T. pallidum antibody using the Syphilis Antibody Rapid Test (Colloidal Gold) (Acon Biotech Co. Ltd., Hangzhou, China), which has a sensitivity of $99.5 \%$ and a specificity of $99.0 \%$. Anti-HIV antibodies were tested with the Diagnostic Kit for HIV (Colloidal Gold) (Livzon Pharmaceutical Group Inc., Zhuhai, China). Each participant had a finger prick and provided about $1 \mathrm{~mL}$ of blood by using the Diagnostic Kit for HBV surface antigen (Colloidal Gold) (product of Livzon Pharmaceutical Group Inc., Zhuhai, China), together with HCV antibody (Colloidal Gold) (product of Livzon Pharmaceutical Group Inc., Zhuhai, China). Product specifications show that the sensitivity and specificity of the colloidal gold kits are both higher than 95\%. Immunochromatographic assay strips are simple, inexpensive, rapid, robust and equipment free, which have been widely used for sexually transmitted diseases screening in many resource-constrained settings [10]. All strips were within the period of validity indicated by the manufacturer. Screening procedures were carried out strictly according to the manufacturer's instructions. 
We collected a $5 \mathrm{~mL}$ blood sample from those with a positive result, immediately transported it to local township hospitals. Whole blood was centrifuged at $1000 \mathrm{rpm}$ for $5 \mathrm{~min}$ and plasma was separated and stored at the constant temperature of $-20^{\circ} \mathrm{C}$ within $8 \mathrm{~h}$, and then were transported in ice to Shanghai. Plasma aliquots were tested for viral load by real-time polymerase chain reaction (PCR). The application of real-time PCR assays with a high specificity $(98.0 \%)$ for secondary syphilis can detect the pathogen directly, and avoid the modification of HIV status [11-13]. Also, there was no further need to consider the syphilis serological window period [13]. We applied the diagnostic kit for the quantification of $T$. pallidum DNA, HBV DNA, HCV RNA, and HIV-1 RNA (PCR-Fluorescence Probing) (DaAn Gene Group Inc., Zhongshan, China) for Plasma viral loads in the Center for Tropical Disease Research at Fudan University. HCV RNA in serum was detected for the majority (95\%) of patients with antibodies [14].

\section{Ethical considerations}

Written informed consents were obtained from all participants. They received the results of the rapid testing on the same day. Those with positive results were provided with appropriate medical consultations, further examinations, and treatments. The procedures of this study were reviewed and approved by the Ethical Review Committee of School of Public Health, Fudan University.

\section{Statistical analysis}

Data entry employed the EpiData software (version 3.1; the EpiData Association, Odense, Denmark). The data processing and analysis was performed with the SPSS software (version 18.0, IBM SPSS Institute, Inc., Chicago). Descriptive statistics were carried out for sociodemographic variables. The proportions of T. pallidum, $\mathrm{HBV}, \mathrm{HCV}$ and HIV infections and co-infections were calculated as well as their $95 \%$ confidence intervals (CIs). Pearson $X^{2}$ test or Fisher's exact test was applied to examine potential variables associated with T. pallidum infection. Crude odds ratios (cORs) along with their 95\% CIs were also calculated. A stepwise logistic regression was employed to build a final multivariable model $(P$ value of retention $\leq 0.05$ ). Adjusted ORs and 95\% CIs were calculated for identified associated factors. Since sex was interacted with some covariates, sex-specific analysis was performed. The statistical significance was symbolized by a two-sided $P$ value $\leq 0.05$.

Quality controlling procedures were followed throughout the process by trained personnel. Skilled local health professionals with medical degrees were employed for blood sample collection and diagnosis at township health clinics. Data accuracy were routinely checked through cross-tabulations and logical checks, Double data entry was taken for data entry quality control.

\section{Results}

A total of 2608 participants over 14 years underwent $T$. pallidum, HBV, HCV, HIV screening tests and completed a questionnaire interview. Demographic characteristics of the participants were summarized in Table 1. Most of them were farmers (91.3\%), ever worked away from home (83.0\%) and were Yi people (96.6\%). Majority of them were female (65.2\%), married (83.6\%) and illiterate (64.7\%).

Among them, $1.2 \%$ (95\% CI 0.8 to 1.7 ) were infected with $T$. pallidum, $5.6 \%$ (95\% CI 4.7 to 6.5 ) with HIV, 7.4\% (95\% CI 6.5 to 8.5 ) with HBV and $2.7 \%$ (95\% CI 2.1 to 3.4 ) with $\mathrm{HCV}$. Only $0.1 \%$ ( $95 \% \mathrm{CI} 0$ to 0.4 ) were coinfected with HIV and T. pallidum, $0.2 \%$ (95\% CI 0 to 0.5 ) with HBV and T. pallidum, and $0.2 \%$ (95\% CI 0 to 0.5 ) with HCV and T. pallidum (Table 2).

Table 3 shows the correlates associated with T. pallidum infection in males and females combined. They were spouse having syphilis $(\mathrm{aOR}=38.51,95 \% \mathrm{CI} 7.12$ to 208.16), injection drug use $(\mathrm{aOR}=3.48,95 \%$ CI 1.14 to 10.57 ), blood transfusion ( $\mathrm{aOR}=5.70,95 \% \mathrm{CI} 1.12$ to 28.97), $\mathrm{HBV}$ infection ( $\mathrm{aOR}=2.76,95 \% \mathrm{CI} 1.00$ to 6.92 ), and $\mathrm{HCV}$ infection $(\mathrm{aOR}=8.34,95 \% 3.01$ to 19.84$)$.

Table 4 shows the results of sex-specific analysis. Injection drug use ( $\mathrm{aOR}=9.42,95 \% \mathrm{CI} 2.47$ to 35.87$)$ and HCV infection ( $\mathrm{aOR}=13.28,95 \% \mathrm{CI} 3.20$ to 51.70$)$ were related to T. pallidum infection in males. Spouse having syphilis (aOR $=126.66,95 \% \mathrm{CI} 7.58$ to 2122.94 ), blood transfution ( $\mathrm{aOR}=10.51,95 \% \mathrm{CI} 1.58$ to 41.21$)$, and $\mathrm{HBV}$ infection (aOR $=4.19,95 \%$ CI 1.35 to 10.93 ) were significantly associated with syphilis in females.

\section{Discussion}

Overall, $1.2 \%$ (95\% CI 0.8 to $1.7 \%$ ) of the study population were infected with $T$. pallidum in this study, which was markedly higher than the estimated prevalence for the 15-59-year group in China (0.02\%) [2]. A high proportion of ever using injection drugs (3.41\%) is likely a main reason for this increased risk of T. pallidum infection in the region.

The correlates varied with sex due to different behavioral characteristics. There is a 'Golden Triangle' in the vicinity of our study sites, where a great number of illicit substances are produced and traded, resulting in a serious epidemic of drug abuse. Males exhibit higher rates of drug abuse and addiction than females [15]. Drug abuse was more common in males $(8.3 \%)$ than females $(0.9 \%)$ in our study. The drug culture of Yi ethnicity was shaped by male masculinity and peer solidarity. Injection and needle sharing were social activities that took place in a collective context [16]. Even in drug users, women 
Table 1 Demographic characteristics of 2608 participants aged $\geq 14$ years

\begin{tabular}{|c|c|}
\hline Characteristics & No. (percentage) \\
\hline \multicolumn{2}{|l|}{ Town } \\
\hline A & $524(20.1 \%)$ \\
\hline B & $571(21.9 \%)$ \\
\hline C & $968(37.1 \%)$ \\
\hline $\mathrm{D}$ & 545 (20.9\%) \\
\hline \multicolumn{2}{|l|}{ Sex } \\
\hline Female & $1700(65.2 \%)$ \\
\hline Male & $908(34.8 \%)$ \\
\hline \multicolumn{2}{|l|}{ Age group (years) } \\
\hline $14-24$ & $413(15.8 \%)$ \\
\hline $25-34$ & $592(22.7 \%)$ \\
\hline $35-44$ & $772(29.6 \%)$ \\
\hline $45-54$ & $558(21.4 \%)$ \\
\hline$\geq 55$ & $273(10.5 \%)$ \\
\hline \multicolumn{2}{|l|}{ Ethnicity } \\
\hline Yi & $2519(96.6 \%)$ \\
\hline Han and others & $89(3.4 \%)$ \\
\hline \multicolumn{2}{|l|}{ Education } \\
\hline Illiteracy & $1676(64.3 \%)$ \\
\hline Primary school & $655(25.1 \%)$ \\
\hline High school and above & $277(10.6 \%)$ \\
\hline \multicolumn{2}{|l|}{ Occupation } \\
\hline Farmers & $2382(91.3 \%)$ \\
\hline Students & $150(5.8 \%)$ \\
\hline Others & $54(2.1 \%)$ \\
\hline 'Missing' & $22(0.8 \%)$ \\
\hline \multicolumn{2}{|c|}{ Ever working away from home } \\
\hline No & $442(17.0 \%)$ \\
\hline Yes & $2166(83.0 \%)$ \\
\hline \multicolumn{2}{|l|}{ Annual income } \\
\hline$<1000$ & $407(15.6 \%)$ \\
\hline 1000-2999 & 922 (35.4\%) \\
\hline 3000-4999 & $603(23.1 \%)$ \\
\hline 5000-9999 & 321 (12.3\%) \\
\hline$\geq 10,000$ & 331 (12.7\%) \\
\hline 'Missing' & $24(0.9 \%)$ \\
\hline \multicolumn{2}{|l|}{ Marital status } \\
\hline Married & 2181 (83.6\%) \\
\hline Unmarried & 427 (16.4\%) \\
\hline
\end{tabular}

only shared needles with their sexual partners, while in male injectors, needle sharing were more likely to occur with peer activities. Intravenous drug users (IDUs) had a higher prevalence of syphilis, which is consistent with
Table 2 Prevalence of T. pallidum, HIV, HBV and HCV infections and coinfections

\begin{tabular}{llll}
\hline & No. Cases & Prevalence (\%) & $95 \% \mathrm{Cl}$ \\
\hline T. pallidum & 32 & 1.2 & $0.8-1.7$ \\
HIV & 145 & 5.6 & $4.7-6.5$ \\
HBV & 194 & 7.4 & $6.5-8.5$ \\
HCV & 71 & 2.7 & $2.1-3.4$ \\
$\begin{array}{l}\text { Co-infected with HIV } \\
\text { and T. pallidum }\end{array}$ & 4 & 0.1 & $0-0.4$ \\
$\begin{array}{l}\text { Co-infected with HBV } \\
\text { and T. pallidum }\end{array}$ & 6 & 0.2 & $0-0.5$ \\
$\begin{array}{l}\text { Co-infected with HCV } \\
\text { and T. pallidum }\end{array}$ & 6 & 0.2 & $0-0.5$ \\
\hline
\end{tabular}

the results from previous studies [17-19]. T. pallidum, HIV, HCV and HBV infections share common modes of transmission, leading to co-infections [20, 21]. Syphilis could generate genital ulcers and increase the likelihood of HIV virus shedding [21, 22]. The course of syphilis is accelerated in patients infected with HIV, and these patients frequently exhibit atypical lesions [23, 24].

These pathogens differ in their transmission efficiency with exposure types [25]. Previous studies showed that HCV and T. pallidum transmissions were more efficient than HIV transmission [26, 27]. Our study illuminated that HCV infection, but not HIV infection, was significantly associated T. pallidum infection in men. T. pallidum infection might contribute to HCV/HIV coinfection or HCV infection [26]. A study in FSWs shows that $\mathrm{HCV}$ is spread mainly by blood, rarely by sexual contact [27], which could explain why HCV infection associated with T. pallidum infection only occurred in males. Although HBV infection is not a classical STD, it can be transmitted through sexual contact with low efficiency [28].

In our study, 30 out of the 89 subjects who used drugs had a co-infection. These results highlighted the necessity of routine HCV testing for T. pallidum infected individuals [29], and also suggested that preventing syphilis should be included as a part of HBV control strategies. Targeted trainings for physicians and expanded syphilis screening services for HBV positive individuals are urgently needed [30, 31].

Consistent with previous studies, spouse having syphilis was a risk factor for T. pallidum infection in females [32] while syphilis was associated with drug abuse in males. Sharing syringes and drug related sexual activities dramatically increase the risk of $T$. pallidum infection [33, 34]. IDUs who engage in unprotected sex, place their female spouses at high risk for STDs [35]. It is common for Yi drug users to engage in sexual behaviors with no condom [36], and the proportion of condom use is extremely low [37]. Therefore, females are highly vulnerable to $T$. pallidum infection 
Table 3 Univariate and multivariate analyses of factors associated with syphilis infection

\begin{tabular}{|c|c|c|c|c|}
\hline Variables & No. & Cases (\%) & cOR (95\% Cl) & $\mathrm{aOR}(95 \% \mathrm{Cl})$ \\
\hline \multicolumn{5}{|l|}{ Town } \\
\hline A & 524 & $9(1.7)$ & Ref. & \\
\hline B & 571 & $7(1.2)$ & $0.71(0.25-1.96)$ & \\
\hline C & 968 & $12(1.2)$ & $0.72(0.30-1.78)$ & \\
\hline $\mathrm{D}$ & 545 & $4(0.7)$ & $0.43(0.11-1.36)$ & \\
\hline \multicolumn{5}{|l|}{ Sex } \\
\hline Female & 1700 & $22(1.3)$ & Ref. & \\
\hline Male & 908 & $10(1.1)$ & $0.86(0.38-1.78)$ & \\
\hline \multicolumn{5}{|l|}{ Age group (years) } \\
\hline $14-24$ & 413 & $3(0.7)$ & Ref. & \\
\hline $25-34$ & 592 & $9(1.5)$ & $2.04(0.59-9.71)$ & \\
\hline $35-44$ & 772 & $14(1.8)$ & $2.42(0.78-11.03)$ & \\
\hline $45-54$ & 558 & $4(0.7)$ & $0.97(0.20-5.32)$ & \\
\hline$\geq 55$ & 273 & $2(0.7)$ & $1.03(0.12-6.82)$ & \\
\hline \multicolumn{5}{|l|}{ Ethnicity } \\
\hline Yi & 2519 & $32(1.3)$ & & \\
\hline Han and others & 89 & $0(0.00)$ & & \\
\hline \multicolumn{5}{|l|}{ Education } \\
\hline Illiteracy & 1676 & $25(1.5)$ & Ref. & \\
\hline Primary school & 655 & $4(0.6)$ & $0.42(0.12-1.09)$ & \\
\hline High school and above & 277 & $3(1.1)$ & $0.76(0.17-2.19)$ & \\
\hline \multicolumn{5}{|l|}{ Occupation } \\
\hline Students & 150 & $0(0.00)$ & - & \\
\hline Farmers & 2382 & $31(1.3)$ & $0.70(0.09-5.24)$ & \\
\hline Others & 54 & $1(1.9)$ & Ref. & \\
\hline \multicolumn{5}{|c|}{ Ever working away from home } \\
\hline No & 442 & $5(1.1)$ & Ref. & \\
\hline Yes & 2166 & $27(1.2)$ & $1.08(0.45-3.24)$ & \\
\hline \multicolumn{5}{|l|}{ Annual income } \\
\hline$<1000$ & 407 & $2(0.5)$ & Ref. & \\
\hline 1000-2999 & 922 & $13(1.4)$ & $2.72(0.74-19.00)$ & \\
\hline $3000-4999$ & 603 & $9(1.5)$ & $2.90(0.73-20.91)$ & \\
\hline 5000-9999 & 321 & $5(1.6)$ & $3.06(0.63-23.93)$ & \\
\hline$\geq 10,000$ & 331 & $3(0.9)$ & $1.81(0.27-15.64)$ & \\
\hline \multicolumn{5}{|l|}{ Marital status } \\
\hline Ever married & 2181 & $31(1.4)$ & Ref. & \\
\hline Never married & 427 & $1(0.2)$ & $6.14(0.84-45.12)$ & \\
\hline \multicolumn{5}{|l|}{ Spouse syphilis } \\
\hline No or unknown & 2601 & $30(1.2)$ & Ref. & Ref. \\
\hline Yes & 7 & $2(28.6)$ & $35.39(4.42-180.06)^{* *}$ & $38.51(7.12-208.16)^{* *}$ \\
\hline \multicolumn{5}{|l|}{ Ever using injection drugs } \\
\hline No & 2519 & $28(1.1)$ & Ref. & Ref. \\
\hline Yes & 89 & $4(4.5)$ & $4.32(1.23-11.39)^{*}$ & $3.48(1.14-10.57)^{*}$ \\
\hline
\end{tabular}


Table 3 Univariate and multivariate analyses of factors associated with syphilis infection (Continued)

\begin{tabular}{|c|c|c|c|c|}
\hline Variables & No. & Cases (\%) & cOR $(95 \% \mathrm{Cl})$ & aOR $(95 \% \mathrm{Cl})$ \\
\hline \multicolumn{5}{|c|}{ Having multiple sexual partners } \\
\hline No & 2181 & $22(1.0)$ & Ref. & \\
\hline Yes & 427 & $10(2.3)$ & $2.37(1.06-4.95)^{*}$ & \\
\hline \multicolumn{5}{|l|}{ Condom use } \\
\hline Always or occasionally & 562 & $12(2.1)$ & Ref. & \\
\hline Never & 1442 & $14(1.0)$ & $0.45(0.20-1.00)^{*}$ & \\
\hline \multicolumn{5}{|c|}{ Ever having blood transfusion } \\
\hline No or unknown & 2580 & $30(1.2)$ & Ref. & Ref. \\
\hline Yes & 28 & $2(7.1)$ & $6.96(1.00-24.98)^{*}$ & $5.70(1.12-28.97)^{*}$ \\
\hline \multicolumn{5}{|l|}{ HIV infection } \\
\hline No & 2463 & $28(1.1)$ & Ref. & \\
\hline Yes & 145 & $4(2.8)$ & $2.55(0.73-6.64)$ & \\
\hline \multicolumn{5}{|l|}{ HBV infection } \\
\hline No & 2412 & $26(1.1)$ & Ref. & Ref. \\
\hline Yes & 194 & $6(3.1)$ & $2.99(1.09-6.92)^{*}$ & $2.76(1.00-6.46)^{*}$ \\
\hline \multicolumn{5}{|l|}{ HCV infection } \\
\hline No & 2485 & $26(1.0)$ & Ref. & Ref. \\
\hline Yes & 71 & $6(8.5)$ & $8.87(3.17-21.11)^{* *}$ & $8.34(3.01-19.84)^{* *}$ \\
\hline
\end{tabular}

due to their unprotected sexual contacts with their highrisk husbands.

Blood transfusion and HBV infection were correlated with T. pallidum infection in females. Females have a higher probability to have a blood transfusion. Blood transfusion represents $5.8 \%$ of admissions for birth [38]. There is a great percentage of surgically treated females than males who are blood transfused [39]. Syphilis may facilitate an acquisition of HBV infection because of its ulcerative infection [40]. Lower socioeconomic status of local females may also be a factor [41]. HBV infection is endemic in China, and HBV vaccination rates are lower in females than males partly due to patriarchal tradition [42].

T. pallidum could be transmitted from mother to child in utero [43]. More than half of pregnant women with syphilis have a spontaneous abortion or stillbirth [44]. Inadequately treated $T$. pallidum infection can result in transplacental infection of the fetus, causing perinatal death, prematurity, low birth weight, congenital anomalies or long-term sequelae including deafness and neurological impairment [45]. Improved access to quality antenatal care, including rapid $T$. pallidum testing and latent syphilis treatment, is important for achieving the elimination of congenital syphilis [43, 46]. Policy-makers may expand and fund programs more effectively in future as one part of the broader harm reduction strategy under the China's national HIV/STD control and prevention plan [18]. The Chinese government has also committed to eliminate the mother-to-child transmissions of HIV, syphilis and HBV with an ambitious plan for prenatal screening being executed nationwide. Given the high rate of co-infection with HCV found in this study area, pregnant women should also be screened for HCV.

Male IDUs present a greater risk of T. pallidum transmission to women. Risk reduction programs, such as condoms promotion, Maintenance Therapy programs (MMT) and Needle or Syringe Exchange Programs (NSEPs) should take into account for distinguishing behavior feature between males and females [9]. Education programs should be sensitive to the whole IDU community and emphasize the importance of consistent condom use with their sexual partners.

There are several limitations in this study. There might exist false-negative testing results because of the sensitivity of the colloidal gold kits. Our estimate for the prevalence of T. pallidum infection could be conservative, because many young individuals, who had a higher risk of $T$. pallidum infection, were more likely to search jobs outside and were not able to participate in the study. In addition, the history of drug abuse and other high-risk behaviors relied on self-reporting without further verification, which might result in a misclassification bias for the estimation of associations between study factors and T. pallidum infection. The number of syphilis-infected people was small and there might be a lack of statistical power to detect certain associations. The cross-sectional design did not allow us to assume any causal relationships between associated factors and T. pallidum infection. 
Table 4 Sex-specific univariate and multivariate analyses of factors associated with syphilis infection

\begin{tabular}{|c|c|c|c|c|c|}
\hline \multirow[t]{2}{*}{ Variables } & \multicolumn{3}{|c|}{ Male $(\boldsymbol{N}=608)$} & \multicolumn{2}{|c|}{ Female $(\boldsymbol{N}=1700)$} \\
\hline & $\begin{array}{l}\text { Prevalence } \\
\text { (\%) }\end{array}$ & cOR (95\% Cl) & $\mathrm{aOR}(95 \% \mathrm{Cl})$ & $\begin{array}{l}\text { Prevalence } \\
(\%)\end{array}$ & cOR $(95 \% \mathrm{Cl})$ \\
\hline \multicolumn{6}{|c|}{ Age group (years) } \\
\hline $14-24$ & 0 & - & & 1.3 & Ref. \\
\hline $25-34$ & 1.0 & $0.95(0.09-10.59)$ & & 1.8 & $1.34(0.36-6.64)$ \\
\hline $35-44$ & 2.2 & $2.01(0.24-16.90)$ & & 1.6 & $1.23(0.34-5.96)$ \\
\hline $45-54$ & 0.6 & $0.65(0.03-8.46)$ & & 0.8 & $0.61(0.10-3.58)$ \\
\hline$\geq 55$ & 1.1 & Ref. & & 0.5 & $0.47(0.02-4.07)$ \\
\hline
\end{tabular}

\section{Ethnicity}

Yi 0

Han and others $\quad 1.2$

1.3

\section{Education}

$\begin{array}{lll}\text { Illiteracy } & 2.3 & \text { Ref. } \\ \text { Primary school } & 0 & - \\ \begin{array}{l}\text { High school and } \\ \text { above }\end{array} & 0.6 & 0.25(0.03-2.00)\end{array}$

\section{Occupation}

$\begin{array}{ll}\text { Students } & 0 \\ \text { Farmers } & 1.1 \\ \text { Others } & 0\end{array}$

Ever working away from home

$\begin{array}{lll}\text { No } & 0.6 & 0.59(0.02-3.25) \\ \text { Yes } & 1.2 & \text { Ref. }\end{array}$

\section{Annual income}

$\begin{array}{ll}<1000 & 0 \\ 1000-2999 & 1.0 \\ 3000-4999 & 2.6 \\ 5000-9999 & 1.5 \\ \geq 10,000 & 0\end{array}$

\section{Marital status}

Ever married

Never married

\section{Spouse syphilis}

No or unknown

Yes

$\begin{array}{ll}1.0 & \text { Ref. } \\ 20.0 & 26.54(0.91-217.16)\end{array}$

1.2

1.4

1.8

0

1.2

0.1

1.4

1.3

0.7

1.6

1.0

1.1

1.1

\section{4}

0.4

1.2

50.0
Ref.

$1.13(0.31-3.13)$

$1.56(0.23-5.64)$

aOR $(95 \% \mathrm{Cl})$

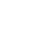


Table 4 Sex-specific univariate and multivariate analyses of factors associated with syphilis infection (Continued)

\begin{tabular}{|c|c|c|c|c|c|c|}
\hline \multirow[t]{2}{*}{ Variables } & \multicolumn{3}{|c|}{ Male $(\boldsymbol{N}=608)$} & \multicolumn{3}{|c|}{ Female $(\boldsymbol{N}=1700)$} \\
\hline & $\begin{array}{l}\text { Prevalence } \\
(\%)\end{array}$ & cOR $(95 \% \mathrm{Cl})$ & $\mathrm{aOR}(95 \% \mathrm{Cl})$ & $\begin{array}{l}\text { Prevalence } \\
\text { (\%) }\end{array}$ & cOR $(95 \% \mathrm{Cl})$ & $\mathrm{aOR}(95 \% \mathrm{Cl})$ \\
\hline \multicolumn{7}{|c|}{ Ever having blood transfusion } \\
\hline No or unknown & 1.1 & & & 1.2 & Ref. & Ref. \\
\hline Yes & 0 & & & 10.5 & $10.32(1.43-39.98)^{*}$ & $10.51(1.58-41.21)^{* *}$ \\
\hline \multicolumn{7}{|l|}{ HIV infection } \\
\hline No & 1.0 & Ref. & & 1.2 & Ref. & \\
\hline Yes & 2.5 & $2.73(0.37-11.42)$ & & 3.1 & $2.78(0.40-9.89)$ & \\
\hline \multicolumn{7}{|l|}{ HBV infection } \\
\hline No & 1.1 & Ref. & & 1.1 & Ref. & Ref. \\
\hline Yes & 1.3 & $1.3(0.06-7.68)$ & & 4.2 & $4.11(1.31-10.71)^{*}$ & $4.19(1.35-10.93)^{* *}$ \\
\hline \multicolumn{7}{|l|}{ HCV infection } \\
\hline No & 0.7 & Ref. & Ref. & 1.2 & Ref. & \\
\hline Yes & 7.4 & $11.18(2.67-41.63)$ & $13.28(3.20-51.70)$ & 11.8 & $11.42(1.58-44.99)^{*}$ & $8.93(0.82-96.97)$ \\
\hline
\end{tabular}

${ }^{*} P<0.05,{ }^{* *} P<0.01$

\section{Conclusions}

The risk of $T$. pallidum infection was high in the rural area of southwestern China, and was significantly associated with spouse having syphilis, drug abuse, blood transfusion and HBV and HCV infections. The correlates of $T$. pallidum infection varied in males and females. It is vital to implement comprehensive and effective intervention programs to reduce the risk of $T$. pallidum transmission and to achieve adequate access to syphilis treatment, especially for people who are IDUs and their spouses.

\section{Supplementary information}

Supplementary information accompanies this paper at https://doi.org/10. 1186/s12889-020-08952-7.

Additional file 1. The questionnaire on behaviors related to infectious diseases among people in Liangshan, A structured questionnaire in English.

\section{Abbreviations}

aORs: Adjusted odds ratios; Cls: Confidence Intervals; cORs: Crude odds ratios; FSWs: Female Sex Workers; HBV: Hepatitis B Virus; HCV: Hepatitis C Virus; HIV: Human Immunodeficiency Virus; IDUs: Intravenous Drug Users; MMT: Maintenance Therapy Programs; NSEPs: Needle or Syringe Exchange Programs; PCR: Polymerase Chain Reaction; STD: Sexually Transmitted Disease; T. pallidum: Treponema pallidum; WHO: World Health Organization

\section{Acknowledgements}

Not applicable.

\section{Authors' contributions}

$Y S$ and $Y Y^{1}$ were responsible for the collection, analysis of data, and wrote the manuscript. $Y W, D Y, Y Y^{2}, S D$ and $C L$ designed the interview questionnaire, performed data collection for the study, laboratory inspection and participated in the interpretation of data. $Y Z$ is corresponding author and responsible for the modification of the manuscript. YC was responsible for technical and language editing. QJ was responsible for ensure that questions related to the accuracy or integrity of any part of the work. All authors read and approved the final manuscript.

\section{Funding}

No funding.

\section{Availability of data and materials}

The datasets used and/or analyzed during the current study are available from the corresponding author on reasonable request.

\section{Ethics approval and consent to participate}

The name of the ethics committee: Ethical Review Committee of School of Public Health, Fudan University.

The ethics committee approval number: IRB\#2017-TYSQ-10-1.

Written informed consents were obtained from participants over the age of 16 and the parents/guardians of children prior to study procedures after they had been clearly informed about the study.

\section{Consent for publication}

Not applicable.

\section{Competing interests}

The authors declare that they have no competing interests.

\section{Author details}

${ }^{1}$ Fudan University School of Public Health, Building 8, 130 Dong'an Road, Xuhui District, Shanghai 200032, China. ${ }^{2}$ Key Laboratory of Public Health Safety, Fudan University, Ministry of Education, Building 8, 130 Dong'an Road, Xuhui District, Shanghai 200032, China. ${ }^{3}$ Fudan University Center for Tropical Disease Research, Building 8, 130 Dong'an Road, Xuhui District, Shanghai 200032, China. ${ }^{4}$ School of Epidemiology and Public Health, Faculty of Medicine, University of Ottawa, 451 Smyth Road, Ottawa, Ontario K1H 8M5, Canada.

Received: 28 July 2019 Accepted: 18 May 2020

Published online: 01 June 2020

\section{References}

1. Peeling RW, Mabey D, Kamb ML, et al. Syphilis. Nat Rev Dis Primers. 2017;3: 17073. https://doi.org/10.1038/nrdp.2017.73.

2. Bureau HC. Notice of the ministry of health on the issuance of the plan for the prevention and control of syphilis in China (2010-2020): The national health commission of the People's Republic of China; 2010. http://www.nhc gov.cn/wjw/gfxwj/201304/bb67c7a0e7c140d7b5ad25ca5106b659.shtml. 
3. Galindo J, Mier JF, Miranda CA, et al. Neurosyphilis: an Age-old Problem that is Still Relevant Today. Rev Colomb Psiquiatr. 2017;46 Suppl 1:69-76. https:// doi.org/10.1016/j.rcp.2017.05.002.

4. Hutchinson CM, Hook ER. Syphilis in adults. Med Clin North Am. 1990;74(6): 1389-416.

5. The L. Congenital syphilis in the USA. Lancet. 2018;392(10154):1168. https:// doi.org/10.1016/S0140-6736(18)32360-2.

6. Chen ZQ, Zhang GC, Gong XD, et al. Syphilis in China: results of a national surveillance programme. Lancet. 2007;369(9556):132-8. https://doi.org/10. 1016/S0140-6736(07)60074-9.

7. Tucker JD, Chen XS, Peeling RW. Syphilis and social upheaval in China [J]. N Engl J Med. 2010;362(18):1658-61. https://doi.org/10.1056/NEJMp0911149.

8. Dai S, Shen Z, Zha Z, et al. Seroprevalence of HIV, syphilis, and hepatitis C virus in the general population of the Liangshan prefecture, Sichuan Province, China. J Med Virol. 2012;84(1):1-5. https://doi.org/10.1002/jmv.22214.

9. Qin S, Li AS, Ma MJ, et al. Unprotected sex with casual partners: a neglected source of HIV transmission among members of the Yi minority in southwestern China. Biomed Environ Sci. 2014;27(10):824-31. https://doi. org/10.3967/bes2014.120.

10. Tucker JD, Bu J, Brown LB, et al. Accelerating worldwide syphilis screening through rapid testing: a systematic review. Lancet Infect Dis. 2010;10(6):3816. https://doi.org/10.1016/S1473-3099(10)70092-X.

11. Koek AG, Bruisten SM, Dierdorp M, et al. Specific and sensitive diagnosis of syphilis using a real-time PCR for Treponema pallidum. Clin Microbiol Infect. 2006;12(12):1233-6. https://doi.org/10.1111/j.1469-0691.2006.01566.x.

12. Gayet-Ageron A, Ninet B, Toutous-Trellu L, et al. Assessment of a real-time PCR test to diagnose syphilis from diverse biological samples. Sex Transm Infect. 2009;85(4):264. https://doi.org/10.1136/sti.2008.034314.

13. Heymans R, van der Helm JJ, de Vries HJC, et al. Clinical Value of \&lt;em\&gt; Treponema pallidum\&lt;/em\&gt; Real-Time PCR for Diagnosis of Syphilis. J Clin Microbiol. 2010;48(2):497. https://doi.org/10.1128/JCM.00720-09.

14. Yun $Z$, Lindh $G$, Weiland $O$, et al. Detection of hepatitis $C$ virus (HCV) RNA by PCR related to HCV antibodies in serum and liver histology in swedish blood donors. J Med Virol. 1993;39(1):57-61. https://doi.org/10.1002/jmv.1890390111.

15. Zhou Y, Zhao M, Zhou C, et al. Sex differences in drug addiction and response to exercise intervention: from human to animal studies. Front Neuroendocrinol. 2016;40:24-41. https://doi.org/10.1016/j.yfrne.2015.07.001.

16. Choi SYP, Cheung YW, Jiang ZQ. Ethnicity and risk factors in needle sharing among intravenous drug users in Sichuan Province, China. AIDS Care. 2007; 19(1):1-8. https://doi.org/10.1080/09540120600900496.

17. Zhou C, Rou K, Dong WM, et al. High prevalence of HIV and syphilis and associated factors among low-fee female sex workers in mainland China: a cross-sectional study. BMC Infect Dis. 2014;14:225. https://doi.org/10.1186/ 1471-2334-14-225.

18. Pan X, Jiang J, He H, et al. Survey of prevalence of HIV infection, syphilis and HCV infection and related risk behaviors among club drug users in Zhejiang, 2011. Zhonghua Liu Xing Bing Xue Za Zhi. 2015;36(9):934-40.

19. Wang BX, Zhang L, Wang YJ, et al. Epidemiology of syphilis infection among drug users at methadone maintenance treatment clinics in China: systematic review and meta-analysis. Int J STD AIDS. 2014;25(8):550-8. https://doi.org/10.1177/0956462413515444.

20. Liu D, Wang Z, Chu T, et al. Gender difference in the characteristics of and high-risk behaviours among non-injecting heterosexual methamphetamine users in Qingdao, Shandong Province, China. BMC Public Health. 2013;13:30. https://doi.org/10.1186/1471-2458-13-30.

21. Mutagoma M, Nyirazinyoye $L$, Sebuhoro D, et al. Syphilis and HIV prevalence and associated factors to their co-infection, hepatitis B and hepatitis C viruses prevalence among female sex workers in Rwanda. BMC Infect Dis. 2017;17(1):525. https://doi.org/10.1186/s12879-017-2625-0.

22. $\mathrm{Hu} \mathrm{QH}, \mathrm{Xu} J$ J, Zou HC, et al. Risk factors associated with prevalent and incident syphilis among an HIV-infected cohort in Northeast China. BMC Infect Dis. 2014;14:658. https://doi.org/10.1186/s12879-014-0658-1.

23. Li D, Yang X, Zhang Z, et al. Incidence of co-infections of HIV, herpes simplex virus type 2 and syphilis in a large cohort of men who have sex with men in Beijing, China. PLoS One. 2016;11(1):e147422. https://doi.org/10. 1371/journal.pone.0147422.

24. Goens JL, Janniger CK, De Wolf K. Dermatologic and systemic manifestations of syphilis [J]. Am Fam Physician. 1994;50(5):1013-20.

25. Shrestha ACGPTB. Co-infection rate of HIV, HBV and Syphilis among HCV seropositive identified blood donors in Kathmandu, Nepal. Infect Ecol Epidemiol. 2012. https://doi.org/10.3402/iee.v2i0.14835.
26. Ruan YH, Hong KX, Liu SZ, et al. Community-based survey of HCV and HIV coinfection in injection drug abusers in Sichuan Province of China. World J Gastroenterol. 2004;10(11):1589-93.

27. Chen Y, Shen Z, Morano JP, et al. Bridging the epidemic: a comprehensive analysis of prevalence and correlates of HIV, hepatitis C, and syphilis, and infection among female sex workers in Guangxi Province, China. PLoS One. 2015;10(2):e115311. https://doi.org/10.1371/journal.pone.0115311.

28. Zhang $X$, Jia M, Chen $M$, et al. Prevalence and the associated risk factors of HIV, STIs and HBV among men who have sex with men in Kunming, China. Int J STD AIDS. 2017;28(11):1115-23. https://doi.org/10.1177/ 0956462416688818.

29. Scherbaum N, Baune BT, Mikolajczyk R, et al. Prevalence and risk factors of syphilis infection among drug addicts. BMC Infect Dis. 2005;5:33. https://doi. org/10.1186/1471-2334-5-33.

30. Tang W, Huang $S$, Chen L, et al. Late Neurosyphilis and tertiary syphilis in Guangdong Province, China: results from a cross-sectional study. Sci Rep. 2017;7:45339. https://doi.org/10.1038/srep45339.

31. Hook ER. Syphilis. Lancet. 2017;389(10078):1550-7. https://doi.org/10.1016/ S0140-6736(16)32411-4.

32. Campos-Outcalt D, Hurwitz S. Female-to-female transmission of syphilis: a case report. Sex Transm Dis. 2002;29(2):119-20.

33. Chen Y, Tang Z, Tang S, et al. Decreasing HIV, syphilis, and hepatitis C infection after a decade of harm reduction implementation among drug users in southwestern areas of China. J Stud Alcohol Drugs. 2018; 79(2):248-57.

34. Sun Y, Guo W, Li G, et al. Increased synthetic drug abuse and trends in HIV and syphilis prevalence among female drug users from 2010-2014 from Beijing, China. Int J STD AIDS. 2018;29(1):30-7. https://doi.org/10.1177/ 0956462417715174.

35. Liao M, Kang D, Tao X, et al. Syndemics of syphilis, HCV infection, and methamphetamine use along the east coast of China. BMC Public Health. 2014;14:172. https://doi.org/10.1186/1471-2458-14-172.

36. Ding $Y$, He N, Zhu W, et al. Sexual risk behaviors among club drug users in Shanghai, China: prevalence and correlates. AIDS Behav. 2013;17(7):2439-49. https://doi.org/10.1007/s10461-012-0380-1.

37. Yang $Y$, Luan RS, Liu $P$, et al. Casual sex and concurrent sexual partnerships among young people from an Yi community with a high prevalence of HIV in China. Asian J Androl. 2012;14(5):758-65. https:// doi.org/10.1038/aja.2012.25.

38. Draogo C M R O, Draogo A O E, Kabore R A J, et al. Analysis of blood transfusion requirements during the gravido-puerperal period in a hospital in Ouagadougou, 2012 [C].

39. Friedman BA, Burns TL, Schork MA. An analysis of blood transfusion of surgical patients by sex: a quest for the transfusion trigger. Transfusion. 1980;20(2):179-88. https://doi.org/10.1046/j.1537-2995.1980.20280169958.x.

40. Xiao Y, Li SL, Lin HL, et al. Factors associated with syphilis infection: a comprehensive analysis based on a case-control study. Epidemiol Infect. 2016;144(6):1165-74. https://doi.org/10.1017/S0950268815002344.

41. Adjei AA, Armah HB, Gbagbo F, et al. Correlates of HIV, HBV, HCV and syphilis infections among prison inmates and officers in Ghana: a national multicenter study. BMC Infect Dis. 2008:8(1):33. https://doi.org/10.1186/14712334-8-33.

42. Yang $Y$, Zhou YB, Cheng WT, et al. A survey of HIV, HBV and HCV infections in children aged 1-13 years in Yi ethnic area, Sichuan province. Zhonghua Liu Xing Bing Xue Za Zhi. 2017;38(9):1165-8. https://doi.org/10.3760/cma.j. issn.0254-6450.2017.09.004

43. Wijesooriya NS, Rochat RW, Kamb ML, et al. Global burden of maternal and congenital syphilis in 2008 and 2012: a health systems modelling study. Lancet Glob Health. 2016;4(8):e525-33. https://doi.org/10.1016/S2214109X(16)30135-8.

44. Tucker JD, Chen XS, Peeling RW. Syphilis and social upheaval in China. N Engl J Med. 2010;362(18):1658-61. https://doi.org/10.1056/NEJMp0911149.

45. Yeganeh N, Watts HD, Camarca M, et al. Syphilis in HIV-infected mothers and infants: results from the NICHD/HPTN 040 study. Pediatr Infect Dis J. 2015;34(3):e52-7. https://doi.org/10.1097/INF.0000000000000578.

46. Garnett GP, Brunham RC. Magic bullets need accurate guns--syphilis eradication, elimination, and control. Microbes Infect. 1999;1(5):395-404.

\section{Publisher's Note}

Springer Nature remains neutral with regard to jurisdictional claims in published maps and institutional affiliations. 